\title{
Towards Marxian Internet Studies
}

\author{
Christian Fuchs
}

Uppsala University, Department of Informatics and Media, Sweden. christian.fuchs@im.uu.se, http://fuchs.uti.at

\begin{abstract}
This article gives an overview of example approaches of Critical Internet Studies and points out key concepts of this field. Critical Cyberculture Studies and Critical Political Economy/Critical Theory of the Internet are identified as two approaches in Critical Internet Studies. The paper also discusses the role of 11 Marxian concepts for Critical Internet Studies. Marxian concepts that have been reflected in Critical Internet Studies include: dialectics, capitalism, commodification, surplus value/exploitation/alienation/class, globalization, ideology, class struggle, commons, public sphere, communism, and aesthetics. The paper points out the importance of explicitly acknowledging the importance of Karl Marx's thinking in Critical Internet Studies. Marx's concepts are today frequently used implicitly, without acknowledging and engaging with their roots. A critique of the approach of "Critical" Cyberculture Studies is advanced. This approach is compared to the approaches of Critical Theory and Critical Political Economy of the Internet. The difference between these two approaches reflects the debate about class exploitation and non-class domination between Cultural Studies and Critical Political Economy in Media and Communication Studies.
\end{abstract}

Keywords: Critical Internet Studies, Critical Cyberculture Studies, Critical Theory of the Internet, Critical Political Economy of the Internet, Karl Marx, Marx is Back

\section{Introduction}

The Internet has become an important socio-technical system that shapes and is shaped by life in contemporary capitalism. Internet Studies has become a crucial field that is engaged in thinking about the transformations of society, individuality, politics, economy, culture, and nature (Fuchs 2008).

As some scholars have argued the third world economy crisis that started as housing and financial crisis, but soon became a world crisis of capitalism, has resulted in a renewed interest in approaches that label themselves as explicitly critical and anti-capitalist (Harvey 2010, Žižek 2009, $2010 b$ ), it is an important task to reflect on the state of those approaches within Internet Studies that label themselves as being explicitly critical. The task of this paper is therefore to provide a short overview of approaches to Critical Internet Studies, to point out key concepts of this field, and to reflect on critiques of Critical Internet Studies. The paper is divided into the discussion of the return of Marx (section 2), Critical Cyberculture Studies (section 3), Critical Political Economy/Critical Theory of the Internet (section 4), a comparison of these two approaches (section 5), a discussion of Critical Internet Studies concepts (section 6), Critiques of Critical Internet Studies (section 7). Finally, some conclusions are drawn (section 8).

\section{Marx is Back}

Eagleton (2011) notes that never a thinker was so travestied as Marx and shows that the contrary of what the common prejudices claim about Marx is the core of his works. Žižek (2010b) argues that the recent world economic crisis has resulted in a renewed interest in the Marxian Critique of the Political Economy. This is shown by the attention recently paid to Marx in the mainstream media. Time magazine, for example, had Marx on its cover and asked about the global financial crisis: What would Marx think? (Time Magazine, February 2, 2009). Hobsbawm (2011, 12f) argues that for understanding the global dimension of contemporary capitalism, capitalism's contradictions and crises and the existence of socio-economic inequality we "must ask Marx's questions" (13). "Economic and political liberalism, singly or in combination, cannot provide the solution to the problems 
of the twenty-first century. Once again the time has come to take Marx seriously" (Hobsbawm 2011, 419).

One interesting thing about Marx is that he keeps coming back at moments, when people least expect it, in the form of various Marxisms that keep haunting capitalism like ghosts, as Derrida (1994) has stressed. It is paradoxical that almost 20 years after the end of the Soviet Union, capitalism seems to have intensified global problems, caused severe poverty and a rise of unequal income distribution, and as a result has brought a return of the economic in the form of a worldwide economic crisis and with it a reactualization of the Marxian critique of capitalism. Although a persistent refrain is "Marx is dead, long live capitalism", Marx is coming back again today.

There are especially six aspects of Marx's works that are relevant for the analysis of contemporary capitalism:

- The globalization of capitalism that is seen as an important characteristic of contemporary society by many social theorists is an important aspect in the works of Marx and Engels (for example: Callinicos 2003). Connected to this topic is also the Marxian theme of international solidarity as form of resistance that seems to be practiced today by the altermondialiste movement.

- The importance of technology, knowledge, and the media in contemporary society was anticipated by the Marxian focus on machinery, means of communication, and the general intellect (see for example: Dyer-Witheford 1999; Fuchs 2008, 2011; Hardt and Negri 2004; McChesney 2007).

- The immizerization caused by neoliberal capitalism suggests a renewed interest in the Marxian category of class (see for example: Harvey 2005).

- The global war against terror after 9/11 and its violent and repressive results like human casualties and intensified surveillance suggest a renewed interest in Marxian theories of imperialism (see for example: Fuchs 2011, chapter 5; Hardt and Negri 2000; Harvey 2003).

- The ecological crisis reactualizes a theme that runs throughout Marxian works: that there is an antagonism between modern industrialism and nature that results in ecological destruction (see for example: O'Connor 1998).

- The new global economic crisis that started in 2008 has shown that Marxist crisis theory is still important today (Foster and Magdoff 2009). Capitalism seems to be inherently crisis-ridden.

Žižek argues that the antagonisms of contemporary capitalism in the context of the ecological crisis, intellectual property, biogenetics, new forms of apartheid and slums show that we still need the Marxian notion of class and that there is a need to renew Marxism and to defend its lost causes in order to "render problematic the all-too-easy liberal-democratic alternative" (Žižek 2008,6) that is posed by the new forms of a soft capitalism that promises and in its rhetoric makes use of ideals like participation, self-organization, and co-operation without realizing them. Therborn argues that the "new constellations of power and new possibilities of resistance" in the $21^{\text {st }}$ century require retaining the "Marxian idea that human emancipation from exploitation, oppression, discrimination and the inevitable linkage between privilege and misery can come only from struggle by the exploited and disadvantaged themselves" (Therborn 2008, 61). Jameson argues that global capitalism, "its crises and the catastrophes appropriate to this present" and global unemployment show that "Marx remains as inexhaustible as capital itself" (Jameson 2011,1) and makes Capital. Volume 1 (Marx 1867) a most timely book.

The implication for Internet Studies is that it should give specific attention to the analysis of how capitalism shapes and is shaped by the Internet. This means that there is a need for rethinking Internet Studies and reorienting it as a Critique of the Political Economy and Critical Theory of the Internet that takes into account the specific character of Marxian analyses of media, technology, and communication, namely to analyze "how capitalist structures shape the media" (McChesney 2007,79 ), the role of communication in the "structure of social relations and [...] social power' with a particular concern for the analysis of that role in the "system of social power called capitalism" (Garnham 1990, 7), and "the analysis of the relationship of media and capitalist society" (Knoche 2005, 105).

In $20^{\text {th }}$ century Marxism, the critical analysis of media, communication, and culture has emerged as a novel quality due to the transformations that capitalism has been undergoing. Early $20^{\text {th }}$ century approaches that gave attention to culture and ideology included the ones by Gramsci, Lukács and Korsch. The latter two thinkers have influenced Frankfurt School Critical Theory (Kellner 1989). Gramsci has had an important influence on British Cultural Studies (Turner 2003). Frankfurt School 
Theory and British Cultural Studies differ in a lot of respects, but have in common the interest in ideology critique. In addition, authors like Adorno, Horkheimer, Marcuse, Benjamin, Williams, or E.P. Thompson had a profound knowledge of, interest in and made thorough use of Marx's works. Cultural Studies has also been influenced by Althusser's theory of ideology (Turner 2003). The focus on ideology has been challenged by Critical Political Economy scholars like Smythe and Garnham, who stress the economic functions of the media, whereas other political economists like Schiller, Golding, Murdock, Herman, Chomsky, McChesney acknowledge the importance of the economic critique of the media, but have continued to also stress the role of media as producers of ideology (Mosco, 2009). More recent developments in Marxist theories of culture and communication have for example been approaches to integrate diverse approaches (for example: Kellner 1995), theories of alternative media that have been implicitly or explicitly inspired by Enzensberger's version of Critical Theory (for example: Downing 2001) and the emergence of the importance of Autonomist Marxism (for an overview see: Virno and Hardt 2006). Marxist Studies of the Internet can make use of this rich history of $20^{\text {th }}$ century Marxism.

Critical Studies of the Internet have been influenced by various strands of Marxist Cultural and Media theory, such as Ideology Critique (see for example the concept of Net Critique: Lovink and Schultz 1997), Autonomist Marxism (Dyer-Witheford 1998; Fuchs 2008; Hakken 2003), Critical Political Economy (Andrejevic 2007, 2009; Fuchs 2009b, 2010a, 2011; Hakken 2003), or Critical Theory (Andrejevic 2009; Fuchs 2008, 2011; Taylor 2009).

\section{Cyberculture Studies and the Un-/Critical}

We can distinguish two broad approaches in Internet Studies that describe themselves as critical. The first have a cultural studies background, the second a political economy background. The theoretical background of the first is, in broad terms, post-structuralist; that of the second is Marxist.

Critical Cyberculture Studies has been positioned explicitly as being an application of Cultural Studies and Postmodernism (Bell 2001, 65-91; Jones 2006, xv-xvi; Sterne 2006). David Bell (2006b) mentions in his introduction to his 4-volume collection Cybercultures. Critical concepts in media and cultural studies 18 influences on Cyberculture Studies. Among them are for example cultural studies, the philosophy of science and technology, feminist studies, and policy studies, whereas approaches such as Critical Theory, Marxism, or critique of the political economy of the media and communication are conspicuous by their absence. The title of Bell's collection promises that one will find "critical concepts" of Internet Studies represented in the 1600 pages of the four volumes, but while reading the 69 chapters, one too often wonders why the critical dimension of the concepts is missing. Exploitation, surplus value, and class on the Internet are marginal issues, whereas topics such as the history of the Internet, research methods, virtual communities, online identities, bodies and minds in cyberspace, and cyborgs are prominently featured. Explicit discussions of Internet capitalism and exploitation, as in the contributions by Dwayne Winseck, Kevin Robins/Frank Webster, or Tiziana Terranova, are marginalized within this volume. The volume lives up to what Bell promises in the introduction - and does therefore not deserve the subtitle "critical concepts".

David Silver (2006b) characterizes "Critical Cyberculture Studies" as the third stage in Cyberculture Studies that followed after Popular Cyberculture Studies and Cyberculture Studies. He characterizes Critical Cyberculture Studies as:

1) exploring "the social, cultural and economic interactions that take place online" (Silver, 2006b, 67),

2) the analysis of discourses about cyberspace,

3) the analysis of access to the Internet,

4) focusing on participatory design (Silver 2006b, 67-73).

Silver advances a shallow notion of the critical. The first quality is extensively broad, the vast majority of analyses of the Internet focuses on social, cultural, or economic issues (except political and ecological analyses), so it remains unclear what shall be specifically critical about "Critical" 
Cyberculture Studies. When discussing the study of "online marginality", Silver stresses the importance of exploring "issues of race, ethnicity and sexuality" (Silver 2006b, 70). The category of class is not mentioned.

David Silver and Adrienne Massanari (2006) present in their collection Critical cyberculture studies 25 readings. In the introduction, Silver (2006a, 6f) mentions capitalism as one context of "Critical Cyberculture Studies", but a much stronger focus is on the "cultural differences" of "race and ethnicity, gender, sexuality, age, and disability" (Silver 2006a, 8). This is also reflected in the volume's contributions, where the analysis of class, surplus value, and exploitation on the Internet are marginal issues, whereas topics relating to "cultural difference" in cyberspace occupy a dominant position.

\section{Critical Political Economy and Critical Theory in Internet Studies}

The second typical approach that can be found in Critical Internet Studies is based on Critical Political Economy and Critical Theory. The sequence of presentation of the following approaches does not reflect an assessment of the importance of approaches, but is based on a chronological order of key works. Included are approaches that use distinctive terms related to critical theory and political economy to characterize themselves.

Geert Lovink and Pit Schultz (1997) argue that "Net Critique" analyzes the organization of power in the immaterial sphere (Lovink and Schultz 1997,6) as well as imperialism and ideology on the Internet (Lovink and Schultz 1997, 11). The goal of Net Critique is free access to all media and all content (Lovink 1997). Net Critique would not be a theory, but a theory-praxis that stands for radical criticism within an exploding electronic public (Lovink and Schultz 1997). Since the Call for Net Critique (Lovink and Schultz 1997) has been published in 1997, a multitude of publications has emerged from the Net Critique Approach (for example: Lovink 2002; Lovink and Scholz 2005; Lovink and Zehle 2005; Jacobs, Janssen and Pasquinelli 2007; Lovink and Rossiter 2007; Rossiter 2006), which has more recently also included a critique of web 2.0 (for example: Lovink 2008; Lovink and Niederer 2008; Rossiter 2006). The Net Critique approach of Lovink and others does not understand itself as a systematic critical theory, but as a very practical form of critique that is therefore also closely related to media activism and media art.

Nick Dyer-Witheford (1999) has suggested reinventing Marxism for the analysis of 21st century techno-capitalism. He terms this project cyber-Marxism. Dyer-Witheford's applies the approach of autonomist Marxism that is represented by scholars like Antonio Negri, Michael Hardt, Paolo Virno, Maurizzio Lazaratto, and others, to Internet Studies. Dyer-Witheford sees Autonomist CyberMarxism as an alternative to the techno-determinism of scientific socialism, the neo-Luddism of the Braverman-inspired technology-as-domination theories, and the techno-euphoria of many theorizations of post-Fordism (Dyer-Witheford 1999, 38-61).

Greg Elmer (2002) sees three characteristics of Critical Internet Studies:

1) the refutation and questioning of ideologies that claim the Internet is revolutionary,

2) the analysis of the "process of Internet corporatization and portalization" (Elmer 2002, x),

3 ) the focus on radical possibilities of the critical Internet community especially the cracks, fissures, and holes in the forms of domination that characterize the Internet.

David Hakken (2003) argues for a knowledge theory of value that is grounded in Marxian theory. He sees cyberspace as being shaped by "vast contradictions" (Hakken 2003, 393). New information- and communication technologies "are better viewed as terrains of contestation than as ineluctable independent forces. Technologies do have politics, but like all politics, they manifest multiple, contradictory tendencies" (Hakken 2003, 366).

Fuchs (2008, 2009a, b; 2010a, b; 2011) speaks of Critical Internet Theory/Studies and the Critique of the Political Economy of the Internet. He argues that these approaches are grounded in more general approaches, especially Frankfurt School Critical Theory and Marx's Critique of the Political Economy that are both foundations for Critical Media and Information Studies (Fuchs 
2011). He thereby undertakes an ontological and epistemological grounding of the critical analysis of the Internet by basing it:

1) on a general social theory level,

2) on the analysis of capitalism,

3) on the critical analysis of media, technology, and communication, and

4) on the specific analysis of the Internet in a critical inquiry that yields emergent qualities.

Fuchs defines Critical Internet Theory/Studies and the Critique of the Political Economy of the Internet as an approach that engages in "identifying and analysing antagonisms in the relationship of the Internet and society; it shows how the Internet is shaped and shapes the colliding forces of competition and cooperation; it is oriented towards showing how domination and exploitation are structured and structuring the Internet and on how class formation and potential class struggles are technologically mediated; it identifies Internet- supported, not yet realized potentials of societal development and radically questions structures that restrain human and societal potentials for cooperation, self-determination, participation, happiness and self-management" (Fuchs 2009b, 75). Fuchs (2011) defines this approach as a unity of philosophically grounded critical theory, empirical research, and praxis-oriented critical ethics.

For Mark Andrejevic (2009), "critical media studies 2.0" challenge the uncritical celebration of the empowering and democratizing character of contemporary media by showing how new media are embedded in old forms of domination. "Thus, when it comes to the revolutionary promise of participatory media, the challenge faced by the proponents and practitioners of a Critical Media Studies 2.0 is not to assert (in all too familiar rhetoric) that, 'everything has changed,' but rather to explain why, even in the face of dramatic technological transformation, social relations remain largely unaltered. To put it bluntly, Critical Media Studies is not interested in media for their own sake, but for society's sake" (Andrejevic 2009, 35). In an approach comparable to the one of Andrejevic, Paul A. Taylor (2009) speaks of Critical Theory 2.0 in order to "describe the manner in which traditional Critical Theory's (1.0) key insights remain fundamentally unaltered" (Taylor 2009, 93), which would be necessary for challenging web 2.0 optimism.

These approaches mainly differ in their understanding of theory, the role that is given to empirical research, the employment of different research methods (such as qualitative interviews, quantitative surveys, content analyses, statistical analyses, critical discourse analyses, or ethnography). For example Dyer-Witheford's cyber-Marxist approach is purely theoretical and based on a reconstruction of Marxian theory for cyberspace. Net Critique tends to discuss examples that are critically reflected upon from theory-inspired positions that are deliberately eclectic and sometimes personal or journalistic and do not form a systematic theoretical whole as in Adorno's prismatic method of exposition. Fuchs on the one hand is keen on basing his approach on a systematic Hegelian dialectical philosophy, in which every category has a clear place in the theoretical system and categories are dialectically developed from the abstract to the concrete level. On the other hand he applies dialectical philosophy at a concrete level as a foundation for empirical studies that make use of a whole range of methods.

Although there are vast theoretical, methodological, epistemological, and ontological differences between various approaches that advance a Critical Theory or the Critical Political Economy of the Internet, there are also commonalities that are especially relating to the normative understanding of criticism. One important commonality is the normative understanding of critique. Critical Internet scholars thereby reflect the old debate between the understanding of critique as epistemologi$\mathrm{cal} /$ methodological and as normative procedure. This issue was already at the heart of the positivism debate in German sociology in 1961. Karl R. Popper (1962) argued that the method of the social consists of gaining and differentiating knowledge by testing solutions to problems. Popper considered this method as critical because scholars question the works of others in order to improve knowledge in trial and error processes. For Popper, critique was an epistemological method that shows logical contradictions. Theodor W. Adorno (1962) argued in contrast to Popper that contradictions are not only epistemological (in the relation of subject-object), but can be inherent in objects themselves so that they cannot be resolved by acquiring new knowledge (Adorno 1962, 551). 
Adorno stressed that Popper's ideal of value-free academia is shaped by the bourgeois concept of value as exchange value (Adorno 1962, 560). He said that positivism is only oriented on appearance, whereas critical theory stresses the difference between essence and appearance (Adorno 1969, 291). He pointed out that Popper's notion of critique is subjective and cognitive (Adorno 1969, 304). There is a fundamental difference between epistemological critique (Popper) and the critique of society (Adorno). Critical Internet scholars question the empiricist application of methods to studying the Internet without grounding the analyses in a thorough analysis in society and in a critical theory of society. This includes some who question all empirical research because they think that the normative falsehood of domination cannot be empirically tested, but only argued for. They all share Adorno's focus on the critique of society.

A second feature that Critical Internet Studies approaches share is the consideration of conventional Internet Studies that dominate the field as forms of instrumental and technological rationality that help legitimize and reproduce capitalism and other forms of domination within capitalism. Instrumental reason means that "ideas have become automatic, instrumentalized" that are not seen as "thoughts with a meaning of their own. They are considered things, machines" for the achievement of the reproduction and deepening of domination (Horkheimer 1974/1947, 15). Technological rationality is another term for instrumental reason, which stresses "elements of thought which adjust the rules of thought to the rules of control and domination" (Marcuse 1964b, 138). Technological rationality denies that reality could be other than it is today. It neglects alternative potentials for development. It aims at "liquidating the oppositional and transcending elements" (Marcuse 1964, 56). Technological rationality causes a one-dimensional thinking, in which "ideas, aspirations, and objectives that, by their content, transcend the established universe of discourse and action are either repelled or reduced to terms of this universe" (Marcuse 1964, 12). Critical Internet scholars consider conventional Internet Studies as ideological because they analyze the Internet as it is, without embedding the analysis into an analysis of structures of domination and without engaging in the struggle for a better world that abolishes domination.

A third commonality concerns the normative and practical levels. Critical Internet Study approaches criticize phenomena that they describe as exploitation, domination, oppression, or exertion of power and structural violence and seek to help advance practices that result in the liberation from these phenomena. Maria Bakardjieva $(2010,61)$ argues that Critical Internet Studies in contrast to statistical and interpretative approaches seeks answers to normative questions relating to the Internet's role in empowerment, oppression, emancipation, alienation and exploitation. Critical studies relate the analysis of the Internet to both domination and liberation. To a larger or lesser degree this involves explicitly the establishment of a post-capitalist society that is for example described as grassroots socialism, communism, participatory democracy, or sustainable information society. The normative dimension is described by such approaches as their emancipatory character.

The critical normative orientation is the central characteristic of Critical Internet Studies. It reflects Horkheimer's insight that critical theory aims at "a state of affairs in which there will be no exploitation or oppression" (Horkheimer 1937/2002, 241). Horkheimer in his essay on Traditional and critical theory reflects Karl Marx's critique of capitalism and reformulated Marxian theory as critical theory of society. One may therefore say that Critical Internet Studies is not only indebted to the Frankfurt School's understanding of critique, but also that the root of this understanding is the theory of Karl Marx. Marx summarized the normative dimension of critical analysis by saying that it grasps "the root of the matter", is based on "the teaching that man is the highest essence for man" and therefore ends "with the categoric imperative to overthrow all relations in which man is a debased, enslaved, abandoned, despicable essence" (MEW Vol. 1, 385). If we understand Marxian critique as the critique of all forms of domination and all dominative relationships, then all critical studies are Marxian-inspired. My argument is that this heritage should not be denied, but taken seriously and positively acknowledged.

The critical normative dimension Critical Internet Studies means that it does not operate in a vacuum, but is on a more general level related to various approaches in the analysis of media, communi- 
cation, technology, culture, and information that also stress the normative critique of domination and the goal of emancipation. It is in this respect especially related to analyses of the critique of the political economy of media and communication, critical theory, and critical information systems research. The Critique of the Political Economy of the Media and Communication ${ }^{1}$ studies the "the power relations, that mutually constitute the production, distribution, and consumption of resources, including communication resources" (Mosco 2009, 2). This approach addresses "how the media system" interacts with and affects "the overall disposition of power in society" (McChesney 2007, 77), and asks "basic moral questions of justice, equity and the public good" (Murdock and Golding 2005,61 ). A critical theory of media and technology analyzes "society as a terrain of domination and resistance and engages in critique of domination and of the ways that media culture engages in reproducing relationships of domination and oppression" (Kellner 1995, 4). It is "informed by a critique of domination and a theory of liberation" (Kellner 1989, 1; see also Feenberg 2002). Critical information systems research produces "knowledge with the aim of revealing and explaining how information systems are (mis)used to enhance control, domination and oppression, and thereby to inform and inspire transformative social practices that realize the liberating and emancipatory potential of information systems" (Cecez-Kecmanovic 2005, 19). Its task is the analysis of the role of information systems in disempowerment and empowerment and to help "overcome injustice and alienation" (Stahl 2008, 9).

\section{Critical Cyberculture Studies and Critical Political Economy/Critical Theory of the Internet}

The main difference that can be found in Critical Internet Studies is the one between Critical Cyberculture Studies and the Critical Political Economy of the Internet. The first approach focuses more on issues relating to the marginalization of identities online, whereas the second has a focus on issues relating to class, exploitation, and capitalism.

When reading "Critical" Cyberculture Studies books and collections, one should remember Nicholas Garnham's insights that "modern forms of racial domination are founded on economic domination" and that "forms of patriarchy have been profoundly marked by the way in which the capitalist mode of production has divided the domestic economy from production as a site of wage labor and capital formation" (Garnham 1998, 610). Critical Political Economy "sees class - the structure of access to the means of production and the structure of the distribution of the economic surplus - as the key to the structure of domination, while cultural studies sees gender and race, along with other potential markers of difference, as alternative structures of domination in no way determined by class" (Garnham 1998, 609). The same difference can be found in Critical Internet Studies. The approach of "Critical" Cyberculture Studies tends to see gender and race in cyberspace as not being necessarily shaped by class. It tends to not see class as the key to understanding domination in cyberspace that has crucial influence on gender, race, and other lines of difference. It tends to ignore topics of class, capitalism, and exploitation. "Critical" Cyberculture Studies is therefore an approach that in its postmodern vein is unsuited for explaining the role of the Internet and communications in the current times of capitalist crisis. The crisis itself evidences the central role of the capitalist economy in contemporary society and that the critical analysis of capitalism and socio-economic class should therefore be the central issue for Critical Internet Studies.

Ernesto Laclau has in a trialogue with Judith Butler and Slavoj Žižek admitted that in postmodern approaches it is a common language game to "transform 'class' into one more link in an enumera-

\footnotetext{
${ }^{1}$ Representatives of this approach, such as Nicholas Garnham, Peter Golding, Robert McChesney, or Graham Murdock, speak of a political economy approach, which is somewhat misleading because political economy is not necessarily critical as indicated by the subtitle of Marx's (1867) main work Capital: A Critique of Political Economy. Marx characterized uncritical political economy as approaches that systematize capitalism "in a pedantic way" by proclaiming capitalism and its constituents for "everlasting truths" (Marx 1867, 174f). As those approaches that are normally discussed in the Anglo-American context under the heading of "political economy of the media and communication" do normally not naturalize and fetishize the specific capitalist form of the media and communicaiton, a self-description as critique of the political economy of the media and communication is more appropriate.
} 
tive chain [...] 'race, gender, ethnicity, etc. - and class" (Butler, Laclau and Žižek 2000, 297) and to put class deliberately as last element in the chain in order to stress its unimportance - Laclau speaks of "deconstructing classes" (Butler, Laclau and Žižek 2000, 296). Slavoj Žižek has in this context in my opinion correctly said that Postmodernism, Cultural Studies, and post-Marxism have by assuming an "irreducible plurality of struggles" accepted "capitalism as 'the only game in town" and have renounced "any real attempt to overcome the existing capitalist liberal regime" (Butler, Laclau and Žižek 2000, 95). Subordinating or equalizing the category of class to other antagonistic categories (gender, ethnicity, age, capabilities, etc) poses the danger of burying the project and demand to establish participatory alternatives to the capitalist totality. The Butler-Laclau-Žižek debate implies for "Critical" Cyberculture Studies that its tendency of neglecting class, exploitation, and capitalism means that it will necessarily have a reformist political agenda and will not be able to conceptualize alternatives to a capitalist Internet in a capitalist society (Fuchs 2011).

All non-class antagonisms are articulated with class, whereas not all non-class antagonisms are articulated with each other. All antagonisms of contemporary society have class aspects and are conditioned by class. Class is the antagonism that binds all other antagonisms together; it prefigures, conditions, enables and constrains, and exerts pressure on possibilities for other antagonisms (Fuchs 2008). At the same time, non-class antagonisms influence the class antagonism so that complex dynamic relationships are present. If class is the super-antagonism of capitalism that does not determine or overdetermine, but condition other antagonisms, then it is important to give specific attention to this category.

According to its own self-descriptions, "Critical" Cyberculture Studies wants to help overcome "online marginalization". It does however very well in marginalizing critiques of how capitalism, class, and exploitation are related to the Internet. It therefore does not deserve the name "critical". "Critical" Cyberculture scholars should take very seriously Douglas Kellner's warning: "Neglecting political economy, celebrating the audience and the pleasures of the popular, overlooking social class and ideology, and failing to analyze or criticize the politics of cultural texts will make me$\mathrm{dia} /$ cultural studies merely another academic subdivision, harmless and ultimately of benefit primarily to the culture industry itself" (Kellner 2009, 19f). It is time for cyberculture scholars to stop purely focusing on their heroes like Donna Haraway, Sherry Turkle, Howard Rheingold, Manuel Castells, and various postmodernists (Bell 2001, 74-88; Bell 2007; Silver 2006b, 65; Silver 2006a, 3) and to substantiate these approaches by reading and interpreting Karl Marx's works.

The number of and interest in analyses of the Internet that are focusing more on class and exploitation have been growing. In the current times of capitalist crisis and the end of postmodernism and culturalism, this development is likely to continue. My argument is that it is time to engage with pleasure in conducting Marxist Internet Studies. We have rather entered times, where it becomes increasingly a matter of explanation why you are not a Marxian scholar.

Truly critical Internet Studies have in common their opposition to positivistic Internet Studies, instrumental/technological rationality, the critique of domination, the struggle for emancipation, and the shared normative grounding in Marxian analysis and various critical analyses of the media, communication, technology, and information. My argument is not only that Internet Studies is in need of Marxian theory, but also that Internet Studies to a certain degree already makes use of Marxian categories and should therefore acknowledge its own Marxian roots.

The next section will focus on the analysis of specific Marxian categories of Critical Internet Studies.

\section{Karl Marx and Critical Internet Studies Concepts}

Critical Internet Studies to a certain degree already makes use of Marxian categories and should therefore acknowledge its own Marxian roots. With the help of examples this circumstance will now be shown especially for eleven Marxian concepts:

1) dialectics

2) capitalism 
3) commodity/commodification

4) surplus value, exploitation, alienation, class

5) globalization

6) ideology/ideology critique

7) class struggle

8) commons

9) public sphere

10) communism

11) aesthetics

Vincent Mosco stresses that Marxian political economy decentres the media by "placing in the foreground the analysis of capitalism, including the development of the forces and relations of production, commodification and the production of surplus value, social class divisions and struggles, contradictions and oppositional movements" (Mosco 2009, 94). To this analysis, six additional crucial Marxian concepts are added: globalization, ideology, commons, public sphere, communism, and aesthetics.

The first relevant Marxian concept is dialectics. Marx applied the Hegelian method of dialectical thinking to the analysis of capitalism. Dialectics is "in its very essence critical and revolutionary" because "it regards every historically developed form as being in a fluid state, in motion, and therefore grasps its transient aspect as well. [...] the movement of capitalist society is full of contradictions" (Marx 1867, 103). Fuchs's approach has an epistemological and ontological focus on dialectical philosophy in order to conceptualize the relationship Internet/web 2.0 and society not as onedimensional and techno-deterministic, but as complex, dynamic, and contradictory (Fuchs 2009b; Fuchs 2011, chapters 2+3). Peter Lunenfeld (1999) and Michael Heim (1999) have spoken of the digital dialectic. Such approaches are related to the dialectical insight of the critical theory of technology that technology is "an 'ambivalent' process of development suspended between different possibilities" (Feenberg 2002, 15).

Marcuse (1941) wanted to avoid deterministic dialectics and to bring about a transition from a structural-functionalist dialectic towards a human-centred dialectic. Therefore he argued that capitalism is dialectical because of its objective antagonistic structures and that the negation of this negativity can only be achieved by human praxis. The Internet or specific Internet platforms have multiple, at least two, potential effects on society and social systems that can co-exist or stand in contradiction to each other (Fuchs 2008, 2011). Which potentials are realized is based on how society, interests, power structures, and struggles shape the design and usage of technology in multiple ways that are also potentially contradictory. One should therefore think about the Internet dialectically just like Marx thought about technology in capitalism as being shaped by an antagonism between productive forces and relations of production. Networked productive forces are in capitalism "antithetical forms", which are at the same time 'mines to explode' capitalism (Marx $1857 / 1858,159)$ and governed by class relations that are 'no longer productive but destructive forces' (Marx and Engels 1846, 60). So for example the services created by Google anticipate a commons-based public Internet from which all benefit and create new potentials for human cooperation, whereas the freedom (free service access) that it provides is now enabled by online surveillance and user commodification that threatens consumer privacy and results in the economic exploitation of users. The solution is not to call for the abolition or replacement of Google, but to argue for its transformation into a publicly organized and controlled search engine (that could for example be run as collaborative project by public universities). The Internet holds at the same time potential for "capitalist spectacle and commodification" and the construction of "cybersituations" that are "aimed at progressive change and alternative cultural and social forms" (Best and Kellner 2001, 237f).

The second cluster of Marxian concepts that is reflected in Critical Internet Studies is capitalism/capitalist mode of production/capitalist society. For Marx, capitalism is a system of capital accumulation, in which the worker "has permission to work for his own subsistence, that is, to live only insofar as he works for a certain time gratis for the capitalist (and hence also for the latter's co- 
consumers of surplus value)" so that "the whole capitalist system of production turns on increasing this gratis labour" (Marx 1875, 310). Therefore this system "is a system of slavery" (Marx 1875, 310). The notion of capitalism/capitalist mode of production is reflected in Critical Internet Studies within concepts such as communicative capitalism (Dean 2004, 2005, 2009, 2010; Passavant 2004), informational capitalism (Fuchs 2008, 2009a; Schmiede 2006), the antagonism of the networked digital productive forces and the relations of production (Fuchs 2008, 2009b; Žižek 2004, 293), digital capitalism (Schiller 2000), hypercapitalism (Graham 2006), or new media/digital visual capitalism (Nakamura 2008). David Beer argues that in studying web 2.0 and social networking sites what is missing is "a more political agenda that is more open to the workings of capitalism" (Beer 2008, 526).

The third important Marxian category is that of commodity/commodification. Marx argues that the fundamental element of capitalism is the commodity, a good that is exchanged in a certain quantitative relationship with money: $\mathrm{x}$ amount of commodity $\mathrm{A}=\mathrm{y}$ units of money. "A given commodity, $\mathrm{a}$ quarter of wheat for example, is exchanged for $x$ boot-polish, y silk or $z$ gold, etc. In short, it is exchanged for other commodities in the most diverse proportions" (Marx 1867, 127). The commodity is for Marx the cell form of capitalism: "The wealth of societies in which the capitalist mode of production prevails appears as an 'immense collection of commodities'; the individual commodity appears as its elementary form" (Marx 1867, 125). Commodification is the transformation of a social relationship into an exchange relationship between buyer and seller. The notion of commodification has been used in Critical Internet Studies for example as the commodification of the Internet (Fuchs 2008, chapter 7), the commodification of online privacy (Campbell and Carlson 2002; Fernback and Papacharissi 2007), the commodification of community in cyberspace (Campbell 2008; Fernback 2004), and the concept of profiling as online commodification machine of personal information (Elmer 2004).

Fourth, one finds the concepts of class, surplus value, exploitation, and alienation in Critical Internet Studies. These notions are inherently related for Marx. Their connection is neatly summarized in the following passage: "On the one hand, the process of production incessantly converts material wealth into capital, into means of creating more wealth and means of enjoyment for the capitalist. On the other hand, the labourer, on quitting the process, is what he was on entering it, a source of wealth, but devoid of all means of making that wealth his own. Since, before entering on the process, his own labour has already been alienated from himself by the sale of his labourpower, has been appropriated by the capitalist and incorporated with capital, it must, during the process, be realised in a product that does not belong to him. Since the process of production is also the process by which the capitalist consumes labour-power, the product of the labourer is incessantly converted, not only into commodities, but into capital, into value that sucks up the valuecreating power, into means of subsistence that buy the person of the labourer, into means of production that command the producers. The labourer therefore constantly produces material, objective wealth, but in the form of capital, of an alien power that dominates and exploits him; and the capitalist as constantly produces labour-power, but in the form of a subjective source of wealth, separated from the objects in and by which it can alone be realised; in short he produces the labourer, but as a wage labourer. This incessant reproduction, this perpetuation of the labourer, is the sine quâ non of capitalist production" (Marx 1867, 716).

Examples for the usage of these Marxian categories in Internet Studies can be given. Fuchs (2010b) argues that capital accumulation is in the corporate 2.0 based on the infinite exploitation of prosumers, who are sold as Internet prosumer commodity to advertising clients. He sees users of the corporate web 2.0 as part of the proletarian class that is exploited by capital (Fuchs 2010b). He bases his analysis on Marx's surplus value concept and Dallas Smythe's notion of the audience commodity. Mark Andrejevic (2002) and Josh Lauer (2008) argue that the work of being watched in respect to the media is a form of exploitation and productive labour. Discussions about value creation on digital media have become important (see for example also: Bolin 2011, Jakobsson and Stiernstedt 2010). Andrejecvic speaks of "the interactive capability of new media to exploit the work of being watched" (Andrejevic 2002, 239) and Lauer (2008) of consumer surveillance as alienated 
labour. Andrejevic (2009) employs the term exploitation 2.0 in order to stress that exploitation remains a fundamental characteristic of the web 2.0 environment. In another work, Andrejevic (2007) has connected the notion of the work of being watched to the category of the digital enclosure. Terranova (2004) has advanced the concept of the exploitation of free labour on the Internet. For Jonathan Beller, surplus value creation on the Internet is characteristic for a cinematic mode of production (Beller 2006). Lisa Nakamura (2009) describes the racialized exploitation of play workers in online games that are facing maquiladora factory conditions. Also the notion of proletarianization has been used for analyzing social media (Breen 2011). Burston, Dyer-Witheford and Hearn (2010) have edited a special journal issue about "digital labour". Digital labour-conferences like "Digital labour: Workers, authors, citizens" (University of Western Ontario, October 2009; see Burston, Dyer-Witheford and Hearn 2010) and "The Internet as Playground and Factory" (New School, November 2009; see the book Scholz 2012) have achieved extraordinary interest in terms of contributions and attendance. A related question is the one of how class relations have changed in the context of culture, the Internet, networks and information (Fuchs 2008; Hesmondhalgh and Baker 2011; Huws 2003; Mosco and McKercher 2009; Qiu 2009).

The fifth concept is that of globalization. Marx stressed that capitalism has an inherent tendency to globalize because of "the entanglement of all peoples in the net of the world-market" and "the international character of the capitalistic regime" (Marx 1867, 929). The world market, capital export and the global organization of companies are aspects of this capitalist globalization process. Kellner (2002) stresses the importance of Marx's dialectical and critical theory in contemporary "technocapitalism" for understanding that globalization and the Internet are contested terrains composed of oppositions. Harvey (1990), reflecting Marx's insight that "capital by its nature drives beyond every spatial barrier" and that "the means of communication and transport" are connected to "the annihilation of space by time" (Marx 1857/1858, 524), says that the rise of a flexible regime of accumulation in combination with new communication technologies has brought about a new phase of time-space compression of capitalism. For Schiller $(2000,135)$, the Internet is a "transnational consumer medium" that helps networking digital capitalism. Dyer-Witheford $(1999,130)$ says that the Internet is an "electronic pathway" for the "circulation of money, commodities, and power". Webster $(2002,77)$ stresses that ICTs like the Internet 'allow the orchestration of globalised production and marketing strategies and of global financial trade. These approaches reflect the insight of Marx that communication technologies like the Internet are the medium and at the same time outcome of the globalization tendency of capitalism (Fuchs 2008, 110).

The sixth concept is the one of ideology/ideology critique. For Marx, ideology is inverted consciousness, consciousness that is manipulated so that it sees reality other than it is. "In all ideology men and their circumstances appear upside-down as in a camera obscura" (MECW Vol. 5, 14). It is "an inverted consciousness of the world" (MECW Vol. 3, 175). In Capital, Marx (1867) described ideology as the fetishism of commodities that makes social relations appear as characteristics of things and thereby creates "misty realms" of consciousness (Marx 1867, 165). Some examples for ideology critique in Critical Internet Studies can be given: Trebor Scholz (2008) criticizes web 2.0 as marketing ideology. José van Dijck and David Nieborg (2009) argue that web 2.0 optimism is uncritical and an ideology that serves corporate interests. Web 2.0 users would be more passive users than active creators (van Dijck 2009). Eran Fisher (2010a, b) argues that web 2.0 is shaped by a discourse that legitimates capitalism that he characterizes as the new spirit of networks. Marcus Breen (2010) argues that digital determinism is an ideology that shapes the age of Internet capitalism. Jodi Dean applies the commodity fetishism concept to the Internet and speaks of Internet fetishism (Dean 2005, 2009). She (Dean 2005, 2009) criticizes the assumption that online politics is inherently critical and constitutes relevant political activities as ideological and argues that communicative capitalism advances communication without communicability (Dean 2004, 2005, 2009,2010 ) that frequently ideologically blinds users. Drawing on the work of Slavoj Žižek, Dean (2006) argues that politicization of the Internet is not automatically present and must be struggled for. Fuchs characterizes the notion of "participatory web 2.0" (within capitalism) as ideology (Fuchs 2011, chapter 7). Thomas Mathiesen (2004) in the spirit of Horkheimer and Adorno describes the corporate Internet as a system of silent silencing. Dominant Internet ideologies are mostly separat- 
ed from everyday working class reality (Olsson 2006). The rise of new technologies often creates an "eruption of feeling that briefly overwhelms reason" (Mosco 2004, 22). Technological determinism ignores the political economy of events. Social media determinism is an expression of the digital sublime, the development that "cyberspace has become the latest icon of the technological and electronic sublime, praised for its epochal and transcendent characteristics and demonized for the depth of the evil it can conjure" (Mosco 2004, 24).

The seventh Marxian category is class struggle. "The history of all hitherto existing society is the history of class struggle. Freeman and slave, patrician and plebeian, lord and serf, guild-master and journeyman, in a word, oppressor and oppressed, stood in constant opposition to one another, carried on an uninterrupted, now hidden, now open fight" (Marx and Engels 1962, 35f). In Critical Internet Studies, the notion of class struggle is for example reflected in the concept of anti-capitalist Internet play struggles that help to "hack" capitalism (Söderberg 2008) or the notion of Internet as means for the circulation of class struggles (Dyer-Witheford 1999). Related concepts are the electronic fabric of struggle (Cleaver 1998) and electronic civil disobedience (Critical Art Ensemble 1996). In discussing Internet-supported struggles, Kahn and Kellner (2004) say that the Internet is the base and basis for globalization-from-below. Also the real of alternative online media as means of struggle has been explored in this context (Kidd 2003). Class struggle-oriented concepts in Critical Internet Studies have their origin in descriptions of the struggles of the Mexican Zapatistas against neoliberalism and the role of the Internet in these struggles. Later, Hardt's and Negri's (2004) concept of the struggle of the multitude - has become of central importance in such approaches. The multitude consists of "singularities that act in common" (Hardt and Negri 2004, 105), "all those who work under the rule of capital" (ibid., 106). It is shaped by immaterial labour, that is labour "that creates immaterial products, such as knowledge, information, communication, a relationship, or an emotional response" (ibid., 108).

The eighth Marxist category is that of commons. Commons are resources that are essential and basic for the survival of a society, that all need, and that are produced by all. Marx has stressed the common character of knowledge with his concept of the "General Intellect", which is the "power of knowledge, objectified", "general social knowledge" that becomes "a direct force of production" (Marx 1857/1858, 706). He pointed out that knowledge is "brought about partly by the cooperation of men now living, but partly also by building on earlier work" (Marx 1894, 199). Its common character is due to "communal labour, [that] however, simply involves the direct cooperation of individuals" (Marx 1894, 199). The concept of the commons has been applied to the context of knowledge on the Internet that is collectively produced and shared and appropriated by capital (see for example: Dyer-Witheford 1999, 4, 219ff; Fuchs 2010b, 2011; Hardt and Negri 2009, 282; Kidd 2003, Žižek 2010a). Discussions of Internet commons relate especially to free software, Wikipedia, and filesharing.

The concepts of class struggle and the commons are in contemporary Marxism and in critical studies of the Internet especially grounded in Autonomist Marxism, a perspective that Žižek (2008, 354) criticizes (mainly in respect to Hardt and Negri) as celebrating the informational revolution as "the unique chance for overcoming capitalism" and as thereby ignoring the rise of a new frictionless soft capitalism that enabled by IT makes use of a rhetoric consisting of ideals like participation, selforganization, and co-operation without realizing them. Žižek however agrees with Hardt and Negri (2009) that the exploitation of the commons of society (such as knowledge on the Internet, education and culture) justifies at the political level as a form of resistance "the resuscitation of the notion of communism" (Žižek 2008, 429).

The ninth concept is the public sphere. Marx imagined alternatives to the bourgeois state that serves class interests when he described the Paris Commune as a specific kind of public sphere: The commune superseded class rule (Marx 1871, 274), it "was formed of the municipal councillors, chosen by universal suffrage in the various wards of the town, responsible and revocable at short terms" (Marx 1871, 274). "Public functions ceased to be the private property of the tools of the Central Committee. Not only municipal administration, but the whole initiative hitherto exercised by the State was laid into the hands of the Commune" (Marx 1871, 274). The Commune was "the self- 
government of the producers" (ibid., 275), who "administer their common affairs by an assembly of delegates" (ibid., 275), abolished "that class-property which makes the labour of the many the wealth of the few" (ibid., 277), and transformed "the means of production, land and capital, now chiefly the means of enslaving and exploiting labour, into mere instruments of free and associated labour" (ibid., 277) so that a "united co-operative" society (ibid., 277) emerges. Marx asks about such a true public sphere: "what else, gentlemen, would it be but Communism" (ibid., 277)? Habermas' original concept of the public sphere is grounded in this Marxian understanding (see: Habermas 1991, 122-129). Marx saw the bourgeois public sphere ironically (Habermas 1991, 123). "Marx denounced public opinion as false consciousness: it hid before itself its own true character as a mask of bourgeois class interests" (Habermas 1991, 124). Marx's "critique demolished all fictions to which the idea of the public sphere of civil society appealed. In the first place, the social preconditions for the equality of opportunity were obviously lacking, namely: that any person with skill and 'luck' could attain the status of property owner and thus the qualifications of a private person granted access to the public sphere, property and education. The public sphere with which Marx saw himself confronted contradicted its own principle of universal accessibility" (Habermas 1991, 124).

A number of authors has discussed how to apply the notion of the public sphere to the Internet and thereby has also taken into account Habermas' Marxist grounding by describing how the political economy of capitalism can colonize and thereby limit the potential of the Internet to act as a tool that advances the transformation towards a public sphere (for example: Dahlberg 2004; Dahlgren 2005; Paparcharissi 2002). However, most of these authors have ignored Marx's concept of the public sphere as communism that transcends the private control of the means of production and the acknowledgement of this dimension by Habermas. Taking both Marx's and young Habermas's concepts of the public sphere seriously must mean for Critical Internet Studies to discuss what a communist Internet is all about (Fuchs 2011). According to Habermas, the public sphere is not only a normative ideal, but also a concept that allows criticizing the political reality of the media. He has stressed in this context that the liberal public sphere limits its own value of freedom of speech and public opinion because citizens in capitalism do not have same formal education and material resources for participating in the public sphere (Habermas 1991, 227) and that it limits its own value of freedom of association and assembly because big political and economic organizations "enjoy an oligopoly of the publicistically effective and politically relevant formation of assemblies and associations" (Habermas 1991, 228). Critical Internet Studies should especially take a look at how freedom of speech and freedom of assembly are limited by unequal conditions of access (money, education, age, etc) and the domination of visibility and attention by big economic and political organizations.

The tenth concept considered here is communism. Marx and Engels did not mean by the term communism a totalitarian society that monitors all human beings, operates forced labour camps, represses human individuality, installs conditions of general shortage, limits the freedom of movement, etc. For them, communism is a society that strengthens common co-operative production, common ownership of the means of production, and enriches the individual sphere of activities and thereby individuality. The new crisis of capitalism has brought about an interest in the idea of communism (see: Žižek and Douzinas 2010). Marx spoke of "an association of free men, working with the means of production held in common, and expending their many different forms of labourpower in full self-awareness as one single social labour force" (Marx 1867, 171). Communism is "a society in which the full and free development of every individual forms the ruling principle" (Marx 1867, 739). In Critical Internet Studies, scholars have for example spoken about the goal of a communist Internet in a communist society (Fuchs 2011), $21^{\text {st }}$ century communism (Dyer-Witheford 1999, 4), cybernetic communism (Barbrook 2007), or dot.communism (Moglen 2003), an alternative Internet (Atton 2004), or a public-service Net (Patelis 2000, 99). The notion of communism has for Internet Studies special relevance for the question to which extent the common sharing (like on file sharing platforms) and co-operative production of knowledge (like on Wikipedia or in the Free and Open Source Software movement) constitutes foundations of a communist mode of production. Marx has stressed the common character of knowledge with his concept of the "General Intel- 
lect", which is the "power of knowledge, objectified", "general social knowledge" that becomes "a direct force of production" (Marx 1857/1858, 706). He pointed out that knowledge is "brought about partly by the cooperation of men now living, but partly also by building on earlier work" (Marx 1894, 199). Its common character is due to "communal labour, [that] however, simply involves the direct cooperation of individuals" (Marx 1894, 199). The concept of the commons has also been applied to the context of knowledge on the Internet that is collectively produced and shared and appropriated by capital (see for example: Dyer-Witheford 1999, 4, 219ff; Fuchs 2010b, 2011; Hardt and Negri 2009, 282; Žižek 2010a).

The eleventh concept is aesthetics. Marx pointed out that art should not be organized as surplus-value generating labour, but in capitalism can be transformed into this kind of work and thereby can become an object of commodification (Marx 1863, 401). For Marx, communism meant the end of the division of labour, so that all people could engage in artistic activities. "In a communist society there are no painters but only people who engage in painting among other activities" (Marx and Engels 1846, 418). Adorno pointed out based on Marx the relationship of art, capitalism, and communism by arguing that authentic art is non-identical with the logic of capitalism, it neglects instrumental reason: "the function of art in the totally functional world is its functionlessness" (Adorno 1997, 320). In recent years, discussion abouts Marxist aesthetics have been applied to the realm of the Internet, online play, and computer games (see for example: Kline, Dyer-Witheford and De Peuter 2003, Andrejevic 2006, Dyer-Witheford and De Peuter 2009).

The eleven concepts discussed are some of the most frequently invoked Marxian notions in Internet Studies. Others could be added and the discussion extended, but the limited space of this article does not allow discussing these issues at length. The examples given are, however, suggestive of the importance of Marxian theory for critical analysis of the Internet. Certainly such concepts are not only welcomed, but are also opposed. This phenomenon is discussed in the next section.

\section{A Critique of the Critique of Critical Internet Studies}

The use of Marxian concepts in Critical Internet Studies is opposed by two main strategies: 1) antiMarxism, 2) the subsumption of Marxian concepts under the dominant ideology. Both aim at delegitimizing alternatives to the corporate control of the Internet.

The anti-communist strategy is represented by Andrew Keen and Josh Lanier. Andrew Keen, author of the book The Cult of the Amateur: How Today's Internet is Killing Our Culture (Keen 2007), argues that web 2.0 rhetoric has a political agenda and shares Marxist political goals (Keen 2006). Keen sees web 2.0 as a dangerous development and argues that a new web $2.0 \mathrm{com}$ munism will put an end to traditional culture and society. "Without an elite mainstream media, we will lose our memory for things learnt, read, experienced, or heard" (Keen 2006). The fear that haunts him seems to be the fear that capitalism and corporate interests are challenged and could somehow cease to exist. Josh Lanier (2006) argues that web 2.0 results in "digital Maoism", a form of collectivism that is as totalitarian as Maoism and negates individuality.

Such approaches advance the idea that Marxism is dangerous and anti-individualistic, which is an error. Whereas the individual was indeed not greatly valued by Mao or Stalin, it was highly important for Marx, who saw communism as the sublation of the class individual and the rise of the well-rounded individual. Communism is for Marx not the collectivization of life, but the creation of a highly productive post-scarcity economy that is based on wealth for all, the minimization of estranged labour, and the maximization of freely chosen labour. Maximizing self-determined labour has potentials for releasing creative capacities and fostering the maximization of the development powers of all humans. The precondition for Marx is the sublation of the private property of the means of production. "In the real community the individuals obtain their freedom in and through their association" (Marx and Engels 1846, 87). This real community would be the "re-integration or return of man to himself, the transcendence of human self-estrangement" (Marx 1844, 101f), "the positive transcendence of private property as human self-estrangement, and therefore as the real appropriation of the human essence by and for man" (Marx 1844, 102), and "the complete return of man to himself as a social (i.e., human) being" (Marx 1844, 102). Communist society enables the 
"all-round development of individuals, precisely because the existing form of intercourse and the existing productive forces are all-embracing and only individuals that are developing in an all-round fashion can appropriate them, i.e., can turn them into free manifestations of their lives" (Marx and Engels 1846, 464). For Marx, capitalism limits the development potentials of humans because the lack of material resources does not allows them to fully develop their capacities. In communism, there is "the development of individuals into complete individuals" (Marx and Engels 1846, 97). "The approporiation of a totality of instruments of production is, for this very reason, the development of a totality of capacities in the individuals themselves" (Marx and Engels 1846, 96).

For Marx, a communist society or socialist mode of production is based on the principle: "From each according to his abilities, to each according to his needs!" (Marx 1875, 306). This means that in a communist society all goods and services are for free and human activities are self-chosen. The precondition is that "the productive forces have also increased with the all-round development of the individual" and that "all the springs of common wealth flow more abundantly" (Marx 1875, 306). Computer technology plays an important role in achieving a communist society: it allows increasing productivity so that overall wealth can be increased. If class relations are substituted by co-operative relations, these material conditions allow post-scarcity and wealth for all as a basis for free labour (in the self of self-determined, not unpaid!) and free goods and services (in the sense of gratis for all). A communist Internet is only possible in such a communist society. In a communist society, digital goods and services will be created in voluntary co-operative labour and will be available to all for free. Digital commodities and commodities in general cease to exist. Selfdetermined activities online and offline will create a well-rounded individuality that is not a form of digital Maoism, but a true form of freedom realized in a dynamic and self-enhancing dialectic of individuality and collectivism.

The second strategy (ideological subsumption) is represented by Kevin Kelly, who preached the neoliberal credos of liberalization, privatization, and commercialization in relation to IT in the 1990s (see for example: Kelly 1998), argues that the "new web", where people "work toward a common goal and share their products in common, [...] contribute labor without wages and enjoy the fruits free of charge" (Kelly 2009, 118) constitutes a "new socialism" - "digital socialism". The new socialism is for Kelly a socialism, in which workers do not control and manage organizations and the material output they generate. Therefore this notion of socialism should be questioned. For Kelly, socialism lies in collective production, not in democratic economic ownership. If "socialism seeks to replace capitalism by a system in which the public interest takes precedence over the interest of private profit", "is incompatible with the concentration of economic power in the hands of a few", and "requires effective democratic control of the economy" (Frankfurt Declaration of the Socialist International; Socialist International 1951), then Kelly's notion of socialism that is perfectly compatible with the existence of Microsoft, Google, Yahoo, and other web corporations (as indicated by the fact that he lists Google, Amazon, Facebook, and YouTube in his history of socialism), is not at all a notion of socialism, but one of capitalism disguised as socialism. For Rosa Luxemburg, socialism was "a society that is not governed by the profit motive but aims at saving human labour" (Luxemburg 1913/2003, 301). She argued that the "aim of socialism is not accumulation but the satisfaction of toiling humanity's wants by developing the productive forces of the entire globe" (Luxemburg 1913/2003, 447).

Kelly's notion of socialism is incompatible with theoretical concepts of socialism, it is theoretically ungrounded and can be considered as the ideological attempt to redefine capitalism and capitalist exploitation as socialism.

\section{Conclusion}

The analysis of approaches in this paper showed that there are methodological, ontological, and epistemological differences within Critical Internet Studies. Critical Cyberculture Studies is influenced by Cultural Studies, it rather ignores aspects of class and exploitation, and should therefore better be termed "Cyberculture Studies". Critical Theory and Critical Political Economy of the Internet are based on the insight that class is crucial for understanding the structures of exploitation and 
domination that express themselves on the Internet and in other media and that in capitalism, all forms of domination are related to and conditioned by forms of exploitation. Either implicitly or explicitly, a lot of Marxian concepts have been reflected in Critical Internet Studies: dialectics, capitalism, commodification, surplus value/exploitation/alienation/class, globalization, ideology, class struggle, commons, public sphere, communism, aesthetics. Anti-Marxism and subsumption are two strategies that attempt to neutralize the critical role of Marxian concepts in Internet Studies.

The outlined eleven Marxian concepts allow formulating an incomplete research agenda for Critical Internet Studies that includes the following questions:

1) How can the creation, development and the contradictions of the Internet be understood by a dialectical and historical critical theory?

2) What exactly is the role of the Internet in capitalism? How can this role be theorized and empirically measured? Which Internet-based capital accumulation models are there?

3) Which forms of commodification do we find on the Internet and how do they work?

4) Which different forms of surplus value creation are there on the Internet, how do they work? What do users think about them?

5) How does the Internet interact with globalization processes?

6) Which myths and ideologies are there about the Internet? How can they be uncovered, analyzed, and criticized?

7) What is the role of the Internet in class struggles? What are the potentials, realities and limits of struggles for an alternative Internet?

8) What are Internet commons? How does the commodification of the Internet commons work? Which models for strengthening the Internet commons are there?

9) What are the potentials and limits of the Internet for bringing about a public sphere?

10) What is a commons-based Internet? Which forms and models of a commons-based Internet are there? How can the establishment of a commons-based Internet be strengthened?

11) How does the Internet change art and aesthetics? Are there potentials of online art and online aesthetics for challenging the logic of capitalism and to help advancing a different logic?

This paper has attempted to show the importance of Marx for Critical Internet Studies. The results confirm the views of a number of critical media/technology studies and information science scholars, who stress the importance of Marx for studying communication (see especially: Fuchs 2010a). Dallas Smythe called for a "Marxist theory of communication" (Smythe 1994, 258). Murdock and Golding $(2005,61)$ say that "Critical Political Economy of Communications" is "broadly marxisant". Andrew Feenberg has stressed that the critical theory of technology "originates with Marx" (Feenberg 2002, vii) and that Marx provided the first critical theory of technology (Feenberg 2002 , 47). Robert McChesney has argued that Marx is of fundamental importance for communication science because he provided intellectual tools that allow:

1. the critique of capital accumulation in the culture industry,

2. the critique of commodity fetishism,

3. the critique of ideologies that legitimate domination (McChesney 2007, 53-55). Furthermore 4. Marx's own journalistic practice would be a model for critical, independent quality journalism (McChesney, 2007 55-57).

Edward Herman (1998) has stressed that the following elements of Marx's analysis are important for an inquiry of contemporary capitalism and communication:

1. the profit and accumulation drive,

2. the role of technological change,

3. the creation of a reserve army,

4. globalization,

5. instability and crises,

6 . the control of the state by dominating classes.

Gerald Sussmann $(1999,86)$ has emphasized in a special issue of the Journal of Media Economics on the topic of "Political Economy of Communication" that critical communication science is 
based on Marxian thinking: "Marx, one of the first to recognize modern communications and transportation as pillars of the corporate industrial infrastructure". Bernd Carsten Stahl $(2008,10,32)$ has argued that Marx is the root of the critical intention of critical information systems research and critical studies in general.

If Internet Studies is a distinct highly interdisciplinary field (Ess 2011), then Critical Internet Studies can be characterized as a subfield of Internet Studies, which focuses on the analysis of dominative structures and practices on the Internet, Internet-based struggles against domination, and seeks to find ways of using the Internet for liberating humans from oppression, inequality, and exploitation. I have argued in this paper that in the contemporary situation of capitalist crisis it is specifically important that Critical Internet Studies focuses on the analysis of the role of the Internet in capitalism and draws upon the Marxian roots of all critical studies. Some scholars in Critical Internet Studies acknowledge explicitly the importance of Marxian analysis for studying the Internet critically, whereas others refer implicitly to Marx. Authors in Critical Cyberculture Studies tend to bracket issues relating to class and capitalism. It is time to actively remember that Karl Marx is the founding figure of Critical Media and Information Studies and Critical Internet Studies (Fuchs, 2010a, 2011) and that Marxian analyses are crucial for understanding the contemporary role of the Internet and the media in society (see also: Fuchs and Winseck 2011).

Steve Macek (2006) has distinguished between two forms of digital media studies: 1) analyses "typically informed by Marxism, materialist feminism, radical political economy, critical sociology, and social movement theory", 2) "postmodernist and poststructuralist media scholarship" (Macek 2006, 1031f). The first approach is certainly "vastly superior to the other" (Macek 2006, 1038; see also the analyses in Artz, Macek and Cloud 2006). In addition, it needs to be stressed that the second approach is completely out of joint with the capitalist crisis times we have entered.

Marx is back, capitalism is in crisis - therefore we require Marxist Internet Studies if we want to understand the role of the Internet in domination and exploitation and its potential for liberation.

\section{References}

Adorno, Theodor W. 1962. Zur Logik der Sozialwissenschaften. In Soziologische Schriften I, 574-565. Frankfurt/Main: Suhrkamp.

Adorno, Theodor W. 1969. Einleitung zum "Positivismusstreit in der deutschen Soziologie. In Soziologische Schriften I, 280353. Frankfurt/Main: Suhrkamp.

Adorno, Theodor W. 1997. Aesthetic Theory. London: Continuum.

Andrejevic, Mark. 2002. The Work of Being Watched: Interactive Media and the Exploitation of Self-Disclosure. Critical Studies in Media Communication 19 (2): 230-248.

Andrejevic, Mark. 2005. The Work of Watching One Another: Lateral Surveillance, Risk, and Governance. Surveillance \& Society 2 (4): 479-497.

Andrejevic, Mark. 2006. Apprehensions of the Future: Internet Aesthetics and Ideology. In Ideologies of the Internet, edited by Katharine Sarikakis and Daya Thussu, 19-34. London: Hampton Press.

Andrejevic, Mark. 2007. iSpy: Surveillance and Power in the Interactive Era. Lawrence: University Press of Kansas.

Andrejevic, Mark. 2009. Critical Media Studies 2.0: An Interactive upgrade. Interactions: Studies in Communication and Culture 1 (1): 35-51.

Artz, Lee, Steve Macek and Danah L. Cloud, eds. 2006. Marxism and Communication Studies. New York: Peter Lang. Atton, Cris. 2004. An Alternative Internet. Edinburgh: Edinburgh University Press.

Bakardjieva, Maria. 2010.. The Internet in Everyday Life: Exploring the Tenets and Contributions of Diverse Approaches. In The Handbook of Internet Studies, edited by Mia Consalvo and Charles Ess, 59-82. Chicester: Wiley.

Barbrook, Richard. 2007. Imaginary Futures. London: Pluto Press.

Beer, David. 2008. Social Network(ing) Sites. Revisiting the Story So Far: A Response to danah boyd \& Nicole Ellison. Journal of Computer-Mediated Communication 13 (2): 516-529.

Bell, David. 2001. An Introduction to Cybercultures. New York: Routledge.

Bell, David, ed. 2006a. Cybercultures. Critical Concepts in Media and Cultural Studies. New York: Routledge.

Bell, David. 2006b. Introduction: Approaching Cyberculture. In Cybercultures. Critical Concepts in Media and Cultural Studies, Volume I, edited by David Bell, 1-10. New York: Routledge.

Bell, David. 2007. Cyberculture Theorists. New York: Routledge. 
Beller, Jonathan. 2006. The Cinematic Mode of Production. Lebanon, NH: Dartmouth College Press.

Best, Steven and Douglas Kellner. 2001. The Postmodern Adventure. New York: Guilford.

Bolin, Göran. 2011. Value and the Media. Cultural Production and Consumption in Digital Markets. Farnham: Ashgate.

Breen, Marcus. 2010. Digital Determinism: Culture Industries in the USA-Australia Free Trade Agreement. New Media \& Society 12 (4): 657-676.

Breen, Marcus. 2011. Uprising. The Internet's Unintended Consequences. Champaign, IL: Common Ground.

Burston, Jonathan, Nick Dyer-Witheford and Alison Hearn, eds. 2010, Digital Labour. Special issue. Ephemera 10 (3/4): 214-539.

Butler, Judith, Ernesto Laclau and Slavoj Žižek. 2000. Contingency, Hegemony, Universality. London: Verso.

Callinicos, Alex. 2003. An Anti-Capitalist Manifesto. Cambridge, UK: Polity.

Campbell, John Edward and Matt Carlson. 2002. Panopticon.com: Online Surveillance and the Commodification of Privacy. Journal of Broadcasting \& Electronic Media 46 (4): 586-606.

Campbell, John Edward. 2008. Virtually Home: The Commodification of Community in Cyberspace (dissertation). Philadelphia, PA: University of Pennsylvania (January 1, 2008).

Cecez-Kecmanovic, Dubravka. 2005. Basic Assumptions of the Critical Research Perspectives in Information Systems. In Handbook of Critical Information Systems Research, edited by Debra Howcroft and Eileen M. Trauth, 19-46. Cheltenham: Edward Elgar.

Cleaver, Harry .1998. The Zapatistas and the Electronic Fabric of Struggle. In Zapatista!, edited by John Holloway and Eloina Peláez, 81-103. London: Pluto Press.

Critical Art Ensemble. 1996. Electronic Civil Disobedience. New York: Autonomedia.

Dahlberg, Lincoln. 2004. Net-Public Sphere Research: Beyond the "First Phase". Javnost 11 (1): 27-44.

Dahlgren, Peter. 2005. The Internet, Public Spheres, and Political Communication. Political Communication 22 (2): 147-162.

Dean, Jodi. 2004. The Networked Empire: Communicative Capitalism and the Hope for Politics. In Empire's New Clothes. Reading Hardt and Negri, edited by Paul A. Passavant and Jodi Dean, 265-288. New York: Routledge.

Dean, Jodi. 2005. Communicative Capitalism: Circulation and the Foreclosure of Politics. Cultural Politics, 1(1), 51-74.

Dean, Jodi. 2006. Žižek Politics. New York: Routledge.

Dean, Jodi. 2009. Democracy and Other Neoliberal Fantasies. Communicative Capitalism and Left Politics. Durham: Duke University Press.

Dean, Jodi. 2010. Blog Theory. Cambridge: Polity.

Derrida, Jacques. 1994. Specters of Marx. New York: Routledge.

Downing, John. 2001. Radical Media. London: Sage.

Dyer-Witheford, Nick. 1999. Cyber-Marx. Cycles and Circuits of Struggle in High-Technology Capitalism. Urbana, IL: Universiy of Illinois Press.

Dyer-Witheford, Nick and Greg De Peuter. 2009. Games of Empire: Global Capitalism and Video Games. Minneapolis, MN: University of Minnesota Press.

Eagleton, Terry. 2011. Why Marx Was Right. London: Yale University Press.

Elmer, Greg, ed. 2002. Critical Perspectives on the Internet. Lanham: Rowman \& Littlefield.

Elmer, Greg 2004. Profiling Machines. Cambridge, MA: MIT Press.

Ess, Charles 2011. Introduction to Part I. In The Handbook of Internet Studies, edited by Mia Consalvo and Charles Ess, pp. 11-15. Chicester: Wiley.

Feenberg, Andrew. 2002. Transforming Technology: A Critical Theory Revisited. Oxford: Oxford University Press.

Fernback, Jan. 2004. Community as Commodity. Empowerment and Consumerism on the Web. Internet Research Annual 1: $224-230$

Fernback, Jan and Zizi Papacharissi. 2007. Online Privacy as Legal Safeguard: The Relationship among Consumer, Online Portal, and Privacy Policies. New Media \& Society 9 (5): 715-734.

Fisher, Eran. 2010a. Contemporary Technology Discourse and the Legitimation of Capitalism. European Journal of Social Theory 13 (2): 229-252.

Fisher, Eran. 2010b. Media and New Capitalism in the Digital Age. Basingstoke: Palgrave Macmillan.

Foster, John B. and Fred Magdoff. 2009. The Great Financial Crisis. Causes and Consequences. New York: Monthly Review Press.

Fuchs, Christian. 2008. Internet and Society. Social Theory in the Information Age. New York: Routledge.

Fuchs, Christian. 2009a. A Contribution to the Critique of the Political Economy of Transnational Informational Capitalism. Rethinking Marxism 21 (3): 387-402.

Fuchs, Christian. 2009b. Information and Communication Technologies and Society. A Contribution to the Critique of the Political Economy of the Internet. European Journal of Communication 24 (1): 69-87.

Fuchs, Christian. 2010a. Grounding Critical Communication Studies: An Inquiry into the Communication Theory of Karl Marx. Journal of Communication Inquiry 34 (1): 15-41. 
Fuchs, Christian. 2010b. Labor in Informational Capitalism and on the Internet. The Information Society 26 (3): 179-196. Fuchs, Christian. 2011. Foundations of Critical Media and Information Studies. New York: Routledge.

Fuchs, Christian and Dwayne Winseck. 2011. Critical Media and Communication Studies Today. A Conversation. tripleC 9 (2): 247-271.

Garnham, Nicholas. 1990. Capitalism and Communication. London: Sage.

Garnham, Nicholas. 1998. Political Economy and Cultural Studies: Reconciliation or Divorce? In Cultural Theory and Popular Culture, edited by John Storey, 600-612. Harlow: Pearson

Graham, Phil. 2006. Hypercapitalism. New York: Peter Lang.

Habermas, Jürgen. 1991. The Structural Transformation of the Public Sphere. Cambridge, MA: MIT Press.

Hakken, David. 2003. The Knowledge Landscapes of Cyberspace. New York: Routledge.

Hammer, Rhonda and Douglas Kellner. 2009. From Communications and Media Studies through Cultural Studies. In Media/Cultural Studies: Critical Approaches, edited by Rhonda Hammer and Douglas Kellner, ix-xlvii. New York: Peter Lang.

Hardt, Michael and Antonio Negri. 2000. Empire. Cambridge, MA: Harvard University Press.

Hardt, Michael and Antonio Negri. 2004. Multitude. New York: Penguin.

Hardt, Michael and Antonio Negri. 2009. Commonwealth. Cambridge, MA: Belknap Press.

Harvey, David. 1990. The Condition of Postmodernity. Oxford: Blackwell.

Harvey, David. 2003. The New Imperialism. Oxford: Oxford University Press.

Harvey, David. 2005. A Brief History of Neoliberalism. Oxford: Oxford University Press.

Harvey, David. 2010. A Companion to Marx's Capital. London: Verso.

Heim, Micahel. 1999. The Cyberspace Dialectic. In The Digital Dialectic, edited by Peter Lunenfeld, 24-45. Cambridge, MA: MIT Press.

Herman, Edward S. 1998. The Reopening of Marx's System. New Politics 6 (4): 131-135.

Hesmondhalgh, David and Sarah Baker 2011. Creative Labour. Media Work in Three Cultural Industries. London:

Routledge.

Hobsbawm, Eric. 2011. How to Change the World. Marx and Marxism 1840-2011. London: Little, Brown.

Horkheimer, Max. 1937/2002. Traditional and Critical Theory. In Critical Theory, 188-252. New York: Continuum.

Horkheimer, Max. 1947/1974. Eclipse of Reason. New York: Continuum.

Huws, Ursula. 2003. The Making of a Cybertariat. Virtual Work in a Real World. New York: Monthly Review Press.

Jacobs, Katrien, Marije Janssen and Matteo Pasquinelli, eds. 2007. C'LICK ME. A Netporn Studies Reader. Amsterdam: Institute of Network Cultures.

Jakobsson, Peter and Fredrik Stiernstedt. 2010. Pirates of Silicon Valley. State of Exception and Dispossession in Web 2.0. First Monday 15 (7).

Jameson, Frederic. 2011. Representing Capital. London: Verso.

Jones, Steve. 2006. Foreword. Dreams of a Field: Possible Trajectories of Internet Studies. In Critical Cyberculture Studies, edited by David Silver and Adrienne Massanari, ix-xvii. New York: New York University Press.

Kahn, Richard and Douglas Kellner. 2004. New Media and Internet Activism. New Media \& Society 6 (1): 87-95.

Keen, Andrew. 2006. Web 2.0. The Second Generation of the Internet Has Arrived. It's Worse Than You Think. The Weekly Standard, May 16.

Keen, Andrew. 2007. The Cult of the Amateuer: How Today's Internet is Killing Our Culture. New York: Currency.

Kellner, Douglas. 1989. Critical Theory, Marxism and Modernity. Baltimore, MD: Johns Hopkins University Press.

Kellner, Douglas 1995. Cultural Studies, Identity and Politics between the Modern and the Postmodern. New York: Routledge.

Kellner Douglas. 2002. Theorizing Globalization. Sociological Theory 20 (3): 285-305.

Kellner, Douglas. 2009. Toward a Critical Media/Cultural Studies. In Media/Cultural Studies: Critical Approaches, edited by Rhonda Hammer and Douglas Kellner, 5-24. New York: Peter Lang.

Kelly, Kevin. 1998. New Rules for the New Economy. New York: Viking.

Kelly, Kevin. 2009. 009, June 2009. The New Socialism. Wired, June 2009: 116-121.

Kidd Dorothy. 2003. Indymedia.org: A New Communication Commons. In Cyberactivism, edited by Martha McCaughey and Michael Ayers, 47-40. New York: Routledge.

Kline, Stephen, Nick Dyer-Witheford and Greg De Peuter. 2003. Digital Play: The Interaction of Technology, Culture and Marketing. Montreal: McGill-Queen's University Press.

Knoche, Manfred. 2005. Kommunikationswissenschaftliche Medienökonomie als Kritik der Politischen Ökonomie der Medien. In Internationale partizipatorische Kommunikationspolitik, edited Petra Ahrweiler and Barbara Thomaß, pp. 101109. Münster: LIT.

Lanier, Jaron. 2006. The Hazards of the New Online Collectivism. Edge - The Third Culture. Retrieved from http://www.edge.org/3rd culture/lanier06/lanier06 index.html 
Lauer, Josh. 2008. Alienation in the Information Economy. Toward a Marxist Critique of Consumer Surveillance. In Participation and Media Production, edited by Nico Carpentier and Benjamin De Cleen, 41-56. Newcastle: Cambridge Scholars.

Lovink, Geert. 1997. Von der spekulativen Medientheorie zur Netzkritik. Telepolis, January 1.

Lovink, Geert. 2002. Dark Fiber. Tracking Critical Internet Culture. Cambridge, MA: MIT Press.

Lovink, Geert. 2008. Zero Comments. Blogging and Critical Internet Culture. New York: Routledge.

Lovink, Geert and Sabine Niederer, eds. 2008. Video Vortex Reader. Responses to YouTube. Amsterdam: Institute of Network Cultures.

Lovink, Geert and Ned Rossiter, eds. 2007. MyCreativity Reader. A Critique of Creative Industries. Amsterdam: Institute of Network Cultures.

Lovink, Geert and Trebor Scholz, eds. 2005. The Art of Free Cooperation. New York: Autonomedia.

Lovink, Geert and Pit Schultz. 1997. Aufruf zur Netzkritik. In Netzkritik, edited by nettime, 5-14. Berlin: Edition ID-Archiv.

Lovink, Geert and Soenke Zehle, eds. 2005. Incommunicado Reader. Amsterdam: Institute of Network Cultures.

Lunenfeld, Peter. 1999a. Introduction: Screen Grabs: The Digital Dialectic and New Media Theory. In The Digital Dialectic, edited by Peter Lunenfeld, xiv-xxi. Cambridge, MA: MIT Press.

Luxemburg, Rosa. 1913/2003. The Accumulation of Capital. New York: Routledge.

Macek, Steve. 2006. Divergent Critical Approaches to New Media. New Media \& Society 8 (6): 1031-1038.

Marcuse, Herbert. 1941. Reason and Revolution. Hegel and the Rise of Social Theory. New York: Humanity Books.

Marcuse, Herbert. 1964. One-Dimensional Man. New York: Routledge.

Marx, Karl. 1844. Ecomomic and Philosophic Manuscripts of 1844. Mineola, NY: Dover.

Marx, Karl. 1857/1858. The Grundrisse. London: Penguin.

Marx, Karl. 1863. Theories of Surplus Value. Volume 1. London: Lawrence \& Wishart.

Marx, Karl. 1867. Capital: Critique of the Political Economy. Volume 1. London: Penguin.

Marx, Karl. 1871. The Civil War in France. In Selected Works In One Volume, 237-295. London: Lawrence \& Wishart.

Marx, Karl. 1875. Critique of the Gotha Programme. In Selected Works In One Volume, 297-317. London: Lawrence \& Wishart.

Marx, Karl. 1894. Capital. Volume 3. London: Penguin.

Marx, Karl and Friedrich Engels. 1846. The German Ideology. Amherst, NY: Prometheus.

Marx, Karl and Friedrich Engels. 1968. Selected Works in One Volume. London: Lawrence \& Wishart.

Mathiesen, Thomas. 2004. Panopticon and Synopticon as Silencing Systems. In Silently Silenced. Essays on the Creation of Acquiesence in Modern Society, 98-102. Winchester: Waterside Press.

MEW. 1962ff. Marx-Engels-Werke. Berlin: Dietz.

MECW. 1975ff. Marx-Engels-Collected Works. New York: International Publishers.

McChesney, Robert W. 2007. Communication Revolution. New York: New Press.

Moglen, Eben. 2003. The dotCommunist Manifesto. Retrieved August 8, 2010, from http://emoglen.law.columbia.edu/my_pubs/dcm.html\#tex2html2

Mosco, Vincent. 2004. The Digital Sublime. Cambridge, MA: MIT Press.

Mosco, Vincent. 2009. The Political Economy of Communication. London: Sage. $2^{\text {nd }}$ edition.

Mosco, Vincent and Catherine McKercher, eds. 2009. The Laboring of Communication. Will Knowledge Workers of the World Unite? Plymouth: Lexington.

Murdock, Graham and Peter Golding. 2005. Culture, Communications and Political Economy. In Mass Media and Society, edited by James Curran and Michael Gurevitch, 60-83. 4th Edition. New York: Hodder Arnold.

Nakamura, Lisa. 2008. Digitizing Race. Visual Cultures of the Internet. Minneapolis, MN: University of Minnesota Press.

Nakamura, Lisa. 2009. Don't Hate the Player, Hate the Game. The Racialization of Labor in World of Warcraft. Critical Studies in Media Communication 28 (2):128-144.

O'Connor, James. 1998. Natural Causes. New York: Guilford.

Olsson, Tobias. 2006 A Marginal Resource for Civic Identity. The Internet in Swedish Working Class Households. JavnostThe Public 13 (1): 73-88.

Paparcharissi, Zizi. 2002. The Virtual Sphere. The Internet as a Public Sphere. New Media \& Society 4 (1): 9-27.

Passavant, Paul A. 2004. Postmodern Republicanism. In Empire's New Clothes. Reading Hardt and Negri, edited by Paul A. Passavant and Jodi Dean, 1-20. New York: Routledge.

Patelis, Korinna. 2000. The Political Economy of the Internet. In Media Organisations in Society, edited by James Curran, 84-107. London: Arnold.

Popper, Karl R. 1962. Zur Logik der Sozialwissenschaften. Kölner Zeitschrift für Soziologie und Sozialpsychologie 14 (2): 233-248.

Quu, Jack L. 2009. Working-Class Network Society. Communication Technology and the Information Have-Less in Urban China. Cambridge, MA: MIT Press. 
Rossiter, Ned. 2006. Organized Networks. Rotterdam: NAi.

Schiller, Dan. 2000. Digital Capitalism. Cambridge, Mass.: MIT Press.

Schmiede, Rudi. 2006. Knowledge, Work and Subject in Informational Capitalism. In Social informatics: An Information

Society For All?, edited by Jacques Berleur, Markku I. Nurminen and John Impagliazzo, 333-354. New York: Springer.

Scholz, Trebor, ed. 2012. Digital Labor. The Internet as Playground and Factory. New York: Routledge.

Scholz, Trebor. 2008. Market Ideology and the Myths of Web 2.0. First Monday 13 (3).

Silver, David. 2006a. Introduction: Where is Internet Studies. In Critical Cyberculture Studies, edited by David Silver and

Adrienne Massanari, 1-14. New York: New York University Press.

Silver, David. 2006b. Looking Backwards, Looking Forwards: Cyberculture Studies 1990-2000. In Cybercultures. Critical

Concepts in Media and Cultural Studies, Volume II, edited by David Bell, 61-79. New York: Routledge.

Silver, David and Adrienne Massanari, eds. 2006. Critical Cyberculture Studies. New York: New York University Press.

Smythe, Dallas W. 1994. Counterclockwise. Boulder, CO: Westview Press.

Socialist International. 1951. Aims and Tasks of the Socialist International. Retrieved August 8, 2010, from

http://www.socialistinternational.org/viewArticle.cfm?ArticlelD=39

Söderberg, Johan. 2008. Hacking Capitalism. New York: Routledge.

Stahl, Bernd C. 2008. Information Systems: Critical Perspectives. New York: Routledge.

Sterne, Jonathan. 2006. Thinking the Internet: Cultural studies versus the Millennium. In Cybercultures. Critical Concepts in

Media and Cultural Studies, Volume II, edited by David Bell, 80-106. New York: Routledge.

Sussman, Gerald. 1999. On the Political Economy of Communication. Journal of Media Economics 12 (2): 85-87.

Taylor, Paul A. 2009. Critical Theory 2.0 and Im/materiality: The bug in the Machinic Flows. Interactions: Studies in Com-

munication and Culture 1 (1): 93-110.

Terranova, Tiziana. 2004. Network Culture. London: Pluto.

Therborn, Göran. 2008. From Marxism to Post-Marxism? London: Verso.

Turner, Graeme. 2003. British Cultural Studies. London: Routledge.

van Dijck, José. 2009. Users Like You? Theorizing Agency in User-Generated Content. Media, Culture \& Society 31 (1): $41-$ 58.

van Dijck, José and David Nieborg. 2009. Wikinomics and its Discontents: A Critical Analysis of Web 2.0 Business Manifestos. New Media \& Society 11 (5): 855-874.

Virno, Paolo and Michael Hardt, eds. 1996. Radical Thought in Italy. Minneapolis, MN: University of Minnesota Press.

Webster, Frank. 2002. Theories of the Information Society. New York: Routledge.

Žižek, Slavoj, 2004. Revolution at the Gates: Žižek on Lenin. London: Verso.

Žižek, Slavoj. 2008. In Defense of Lost Causes. London: Verso.

Žižek, Slavoj. 2009. First as Tragedy, Then as Farce. London: Verso.

Žižek, Slavoj. 2010a. How to Begin from the Beginning. In The Idea of Communism, edited by Slavoj Žižek and Costas

Douzinas, 209-226. London: Verso.

Žižek, Slavoj. 2010b. Living in the End Times. London: Verso.

Žižek, Slavoj and Costas Douzinas, eds. 2010. The Idea of Communism. London: Verso.

\section{About the Author}

\section{Christian Fuchs}

Christian Fuchs holds the chair professorship in media and communication studies at Uppsala University's Department of Informatics and Media. He is also board member of the Unified Theory of Information Research Group and editor of tripleC (cognition, communication, co-operation): Journal for a Global Sustainable Information Society. His main research fields are: social theory, critical theory, political economy of media, ICTs, communication, information, technology; critical information society studies, ICTs and society. He is author of numerous academic publications, including the books "Internet and Society: Social Theory in the Information Age" (New York: Routledge 2008, paperback edition 2010) and "Foundations of Critical Media and Information Studies" (New York: Routledge 2011). He is co-founder of the ICTs and Society Network and chair of the European Sociological Association's Research Network 18 - Sociology of Communications and Media Research. 